\title{
OPTIMALISASI DANA INFAK MASJID DALAM MENGATASI PERMASALAHAN IURAN BPJS KESEHATAN MASYARAKAT DI LINGKUNGAN MASJID YOGYAKARTA
}

\author{
Nurul Jihadah Ashar, Isnaini Ulfa Rinda Sari' Aisyah Rohma Danita \\ Universitas Ahmad Dahlan Yogyakarta \\ nuruljihadaashar@gmail.com
}

DOI: https://doi.org/10.21107/dinar.v6i1.6467

\begin{abstract}
Abstrak
Urgensi ekonomi bagi masyarakat merupakan aksioma yang tidak terbantabkan. Pengoptimalan dana infak masjid umumnya berputar pada operasional masjid saja. Akan tetapi, pada kenyataannya dana infak dapat dioptimalkean untuk peningkatan kesejabteraan umat. Hal mendasar yang perlu diperhatikan adalah kesehatan masyarakat itu sendiri. Adapun penelitian ini difokuskan pada pengoptimalan dana infak masjid untuk membantu masyarakat dalam membayar iuran Badan Penyelenggara Jaminan Sosial (BPJS) Kesehatan. Penelitian ini dilakukan di Kota Yogyakarta dengan mengambil 6 sampel masjid. Adapun sampel dari penelitian dipilih secara purposive sampling dengan mempertimbangkan beberapa aspek, yaitu jumlah penduduk sekitar masjid, jumlah infak yang belum dimanfaatkan, dan laporan keuangan masjid (penerimaan dan pengeluaran).Tujuan dari penelitian ini adalah terapan karena penelitian ini dilakukan untuk memperoleh informasi yang dapat digunakan untuk menyelesaikan permasalahan pembayaran iuran BPJS di lingkungan masyarakat. Dalam penelitian ini didasarkan pada data sekunder yang dikumpulkan berupa laporan kenangan masjid (dana infak). Kemudian diperoleh data dana infak masjid yang belum dimanfaatkan untuk dialokasikan kepada masyarakat sehingga mampu membantu dalam mengatasi pembayaran iuran BPJS Kesehatan.
\end{abstract}

Kata Kunci : Infak, masjid, BPJS Kesehatan 


\section{Pendahuluan}

Dalam sejarah Islam membuktikan bahwa masjid merupakan pusat atau sentral kegiatan kaum muslim baik dalam hal ibadah, ekonomi maupun sosial, sebagaimana keberadaan masjid nabawi di Madinah pada masa Rasulullah SAW. Begitupun di Indonesia, masjid juga memainkan peran penting dalam kehidupan masyarakat (Sidi Gazalba, 1983). Selain sebagai tempat ibadah maupun sarana penyebaran agama Islam, para pengurus masjid juga menyediakan wadah bagi masyarakat yang ingin berinfak ataupun shodaqoh khususnya pada hari-hari besar Islam seperti hari raya Idul Fitri, Idul Adha dan pada saat shalat jum'at setiap minggunya.

Dana yang dikumpulkan kemudian digunakan untuk biaya operasional masjid seperti membayar khotib, imam, muadzin, takmir dan lain-lain. Selain itu, digunakan pula untuk biaya renovasi serta pembangunan infrastruktur masjid (Sochimin, 2016). Berkaitan dengan pemakmuran masjid, sebenarnya banyak berhubungan dengan kemakmuran masyarakat Islam secara umum karena menurut Masjid kata ma'mur dapat diobsesikan dengan perkataan ta'mir (takmir). Jadi, takmir masjid adalah lembaga atau badan yang bertanggungjawab untuk membuat masjid ramai dan sejahtera. Dengan demikian masjid memiliki peran yang vital dalam membangun masyarakat yang tinggal di lingkungannya.

Pada kenyataannya fungsi masjid yang ada dewasa ini sebagian besarnya hanya terbatas sebagai tempat ibadah ritual saja. Hal ini berbeda dengan fungsi masjid pada zaman Rasulullah SAW. Pada masa Rasulullah SAW fungsi masjid di samping sebagai tempat ibadah ritual juga memiliki fungsi penunjang seperti fungsi pendidikan, informasi, kesehatan, ekonomi, bahkan juga digunakan untuk mengatur Negara dan strategi perang. Ada beberapa keuntungan jika potensi ekonomi masjid dapat dikembangkan, yaitu: 1) dapat membantu pemerintah dalam mengurangi angka kemiskinan;, 2) dapat mengurangi ketergantungan pemerintah kepada pinjaman luar negeri untuk program pengentasan kemiskinan; dan 3) dapat dipergunakan untuk membangun kemandirian ekonomi umat (Rifai \& Fakhruroji, 2005).

Untuk menjadikan masjid berfungsi sebagaimana mestinya dan sebagai tempat strategis pembinaan ekonomi umat, maka perlu dibuatkan pemodelan pemberdayaan ekonomi masjid melalui optimalisasi fungsi dan potensi masjid. Pemodelan pemberdayaan ini dapat dilakukan melalui identifikasi potensi ekonomi masjid yang tersedia meliputi sumber daya manusia, potensi masyarakat sekitar masjid, dan lain-lain.

Hak tingkat hidup yang memadai untuk kesejahteraan masyarakat merupakan hak asasi manusia dan diakui secara internasional termasuk Indonesia. Oleh karena itu, pemerintah melalui undang-undang tentang Jaminan Kesehatan Nasional (JKN) dengan mewajibkan seluruh masyarakat mengikuti program jaminan kesehatan berupa asuransi kesehatan sosial yang dikelola oleh badan penyelenggara jaminan kesehatan (BPJS).

Jaminan Kesehatan Nasional (JKN) berupa BPJS kesehatan memberikan beberapa keuntungan yaitu, memberikan manfaat yang komprehensip dengan premi terjangkau, BPJS Kesehatan menerapkan prinsip kendali biaya dan mutu, menjamin sustainabilitas 
(kepastian pembiayaan pelayanan kesehatan yang berkelanjutan), serta memiliki portabilitas sehingga dapat digunakan di seluruh wilayah Indonesia.

Namun demikian, sistem JKN oleh BPJS menjadi persoalan tersendiri karena negara mengalihkan tanggung jawab penjaminan kesehatan menjadi kewajiban seluruh masyarakat yang bersifat mandatorik. Kewajiban inilah yang menjadikan beban masyarakat bertambah karena pengeluaran yang dibayarkan langsung dari uang saku sendiri sehingga mengakibatkan masyarakat yang berpendapatan rendah merasa keberatan dibandingkan dengan masyarakat yang berpendapatan tinggi. Dengan kata lain, sistem ini memberikan beban tersendiri bagi masyarakat golongan bawah. Maka, pengoptimalisasian dana infak masjid akan menjadi solusi alternatif dalam mengatasi persoalan iuran BPJS bagi masyarakat di sekitar lingkungan masjid.

Oleh karena itu, tim penulis tertarik untuk menganalisis teori tersebut ke dalam studi penelitian dengan judul "Optimalisasi Dana Infak Masjid dalam Mengatasi Permasalahan Iuran BPJS Kesehatan Masyarakat di Lingkungan Masjid Yogyakarta”.

\section{Tinjauan Pustaka}

1. Infak

Menurut UU No.23 Tahun 2011 tentang pengelolaan zakat dijelaskan bahwa infak adalah harta yang dikeluarkan oleh seseorang atau badan usaha diluar zakat untuk kemaslahatan umum.Infak adalah pemberian atau sumbangan harta selain zakat untuk kebaikan.

Menginfakkan harta secara baik dan benar termasuk ketaqwaan manusia kepada Allah SWT. Infak yang diberikan akan menjadi salah satu pemasukan dana sosial, yang tidak terikat jumlah dan waktunya. Infak tidak mengenal nishab, infak dikeluarkan oleh seiap orang yang beriman, baik yang berpenghasilan tinggi maupun rendah (Nurlaelawati, 2010).

Shadaqah adalah suatu pemberian yang diberikan oleh seorang muslim kepada orang lain secara spontan dan sukarela tanpa dibatasi waktu dan jumlah tertentu, suatu pemberian yang diberikan oleh seseorang sebagai suatu kebajikan yang mengharap ridha Allah SWT dan pahala semata.

Dalam terminologi syariah, pengertian shadaqah berarti mengeluarkan sebagian harta atau penghasilan untuk kepentingan yang diperintahkan dalam ajaran islam.Jadi, infak dan shadaqah memiliki tujuan untuk mensejahterakan umat dan mengajarkan untuk selalu berbagi kepada sesama dengan memberikan sebagian harta yang kita miliki (Priyatna, 2018).

\section{Masjid}

Masjid dapat didefinisikan sebagai "suatu bangunan, gedung atau suatu lingkungan yang memiliki batas yang jelas (benteng/pagar) yang didirikan secara khusus sebagai tempat beribadah umat Islam kepada Allah SWT, khususnya untuk menunaikan shalat (Nasution Abdul Haris, Khoirun, Askari, \& Muhammad, n.d.). 
Menilik dari sejarah peradaban Islam, masjid merupakan sarana untuk melakukan dakwah sekaligus memberdayakan ekonomi jamaah dan masyarakat yang ada di sekitar masjid. Masjid juga berperan dalam menyelesaikan persoalan pendidikan, sosial budaya, sosial kemasyarakatan, dan terutama sosial ekonomi masyarakat (Rifai \& Fakhruroji, 2005).

Indonesia merupakan negara dengan jumlah penduduk muslim terbesar di dunia. Berdasarkan sensus penduduk yang dilakukan BPS pada tahun 2010, jumlah penduduk muslim di Indonesia sejumlah 237.641.326 jiwa atau 87,18 persen penduduk di Indonesia.

Selain jumlah penduduk muslim yang besar, jumlah masjid di Indonesia mencapai kurang lebih 290.000 bangunan. Hal ini disampaikan oleh ketua umum Dewan Masjid Indonesia, Jusuf Kalla. Jadi, dengan jumlah masjid dan jumlah penduduk yang tergolong besar tersebut, pemberdayaan ekonomi masyarakat melalui masjid dapat dioptimalisasikan 3. BPJS Kesehatan (Badan Penyelenggara Jaminan Sosial Kesehatan)

BPJS Kesehatan merupakan Badan Hukum Publik yang bertanggungjawab langsung kepada Presiden dan memiliki tugas untuk menyelenggarakan Jaminan Kesehatan Nasional bagi seluruh rakyat Indonesia, terutama untuk Pegawai Negeri Sipil, Penerima Pensiun PNS dan TNI/POLRI, Veteran, Perintis Kemerdekaan, beserta keluarganya dan Badan Usaha lainnya atau pun rakyat biasa (Usman \& Kara, 2016).

BPJS Kesehatan ini merupakan penyelenggara program jaminan sosial di bidang kesehatan yang merupakan salah satu dari lima program dalam Sistem Jaminan Sosial Nasional (SJSN), yaitu Jaminan Kesehatan, Jaminan Kecelakaan Kerja, Jaminan Hari Tua, Jaminan Pensiun, dan Jaminan Kematian sebagaimana tercantum dalam Undang-Undang Nomor 40 Tahun 2004 tentangSistem Jaminan Sosial Nasional.

BPJS Kesehatan juga menjalankan fungsi pemerintah (governing function) di bidang pelayanan umum (public services) yang sebelumnya sebagian dijalankan oleh badan usaha milik negara dan sebagian lainnya oleh lembaga pemerintah. Gabungan antara kedua fungsi badan usaha dan fungsi pemerintah itulah yang dewasa ini, tercermin dalam status BPJS Kesehatan sebagai badan hukum publik yang menjalankan fungsi pelayanan umum di bidang penyelenggaraan jaminan sosial nasional (Abdul Muta Ali, 2018).

\section{Tabel 1}

Data pembayaran dan tunggakan BPJS

\begin{tabular}{|c|c|}
\hline Tahun & Tunggakan \\
\hline 2014 & 1,9 \\
\hline 2015 & 9,4 \\
\hline 2016 & 6,7 \\
\hline 2017 & 13,8 \\
\hline 2018 & 19,4 \\
\hline
\end{tabular}

Sumber: Data Diolah

Banyak peserta mandiri yang hanya mendaftar pada saat sakit dan memerlukan layanan kesehatan berbiaya mahal sedangkan peserta tidak tertib dalam membawa iuran 
BPJS kesehatan. Sepanjang tahun 2018, klaim rasio dari peserta mandiri mencapai 313\%. Taken 2018 total iuran peserta mandiri 8,9 triliun sedangkan total ultimate mencapai 27,9 triliun berarti tjngkat keaktifan peserta mandiri hanya 53,7 \%. Jumlah terdaftar peserta BPJS 199 juta jiwa atau sekitar 80\% Dari keseluruhan populasi penduduk Indonesia. PBI APBN 92,3 juta, PPI swasta 27,9 juta, PBNU pekerja mandiri 27,6 juta, PBI APBD 25,1 juta, PPU PNS 14,1 juta, Bukan pekerja 5,1 juta, PPU TNI 1,6 juta, PPU BUMN 1,5 juta, PPU polri 1,3 juta, PPU BUMD 180,6 ribu. Sementara jumlah fasilitas kesehatan BPJS kesehatan hingga Mei tahun 2018 mencapai 27.140. Yang terdiri dari puskesmas 6.666 unit, puskesmas+TT 3.206 unit, klinik rawat inap 497 unit dan rumah sakit 2.159 unit.

4. Penyebab Defisit BPJS Kesehatan

a. Besarnya klaim yang harus dibayarkan BPJS Kesehatan untuk menanggung pengobatan selalu lebih tinggi dari total iuran yang dibayarkan oleh pesertanya. Rasio klaim terhadap penerimaan selalu di atas $100 \%$.

b. Tarif iuran yang masih rendah, underpriced atau di bawah angka hitungan ideal untuk bisa menutupi biaya kesehatan.

c. Peserta JKN yang tidak disiplin. Banyak peserta PBPU atau dari sektor informal yang baru mendaftar pada saat sakit. Tetapi setelah mendapat layanan kesehatan, mereka berhenti membayar iuran.

d. Rendahnya tingkat keaktifan peserta membayar iuran. Tingkat keaktifan membayar iuran peserta PBPU tercatat hanya sekitar 54\%. Artinya, 46,3\% dari peserta mandiri yang menunggak membayar iuran. Sepanjang 2016 sampai 2018, besar tunggakan peserta mandiri mencapai sekitar Rp 15 triliun. Sementara tingkat utilisasi (penggunaan asuransi) sangat tinggi, dengan rasio klaimnya mencapai 313\%.

e. Beban pembiayaan untuk penyakit katastropik yang harus ditanggung BPJS Kesehatan sudah sangat besar. Katastropik adalah penyakit-penyakit yang membutuhkan biaya tinggi dalam pengobatannya, seperti kanker, jantung, dan gagal ginjal.

5. Kriteria Penerima PBI

a. Peserta PBI Jaminan Kesehatan meliputi orang yang tergolong fakir miskin dan orang tidak mampu.

b. Kriteria Fakir Miskin dan orang tidak mampu ditetapkan oleh menteri di bidang sosial setelah berkoordinasi dengan menteri dan / atau pimpinan lembaga terkait

c. Kriteria Fakir Miskin dan Orang tidak mampu sebagaimana dimaksud menjadi dasar bagi lembaga yang menyelenggarakan urusan pemerintahan di bidang statistik untuk melakukan pendataan

d. Data Fakir Miskin dan Orang Tidak Mampu yang telah diverifikasi dan divalidasi sebagaimana dimaksud, sebelum ditetapkan sebagai data terpadu oleh Menteri di bidang sosial, dikoordinasikan terlebih dahulu dengan menteri yang menyelenggarakan urusan pemerintahan di bidang keuangan dan menteri dan/atau pimpinan lembaga terkait. 
e. Data terpadu yang ditetapkan oleh Menteri dirinci menurut provinsi dan kabupaten/kota.

f. Data terpadu sebagaimana dimaksud menjadi dasar bagi penentuan jumlah nasional PBI Jaminan Kesehatan.

g. Data terpadu sebagaimana dimaksud, disampaikan oleh Menteri di bidang sosial kepada menteri yang menyelenggarakan urusan pemerintahan di bidang kesehatan dan DJSN.

6. Masalah Kenaikan Iuran BPJS

a. Inflasi

Kenaikan iuran tersebut secara langsung juga pasti akan berpengaruh terhadap inflasi. Di mana, kenaikan iuran BPJS Kesehatan akan mendorong administered price atau harga yang diatur pemerintah melonjak lebih tinggi dari sebelumnya. Menurut Direktur Eksekutif Institute for Development of Economic and Finance (Indef) Tauhid Ahmad kenaikan iuran sebesar dua kali lipat akan berdampak pada kesejahteraan masyarakat. Sebab, biaya yang dikeluarkan untuk jaminan kesehatan meningkat.

b. Kemiskinan

Wali Kota Solo F.X. Hadi Rudyatmo termasuk salah satu pejabat yang tidak setuju dengan kenaikan iuran BPJS Kesehatan. Dia mengungkap 'bahaya laten' membesarnya angka kemiskinan di Indonesia akibat kebijakan ini.Jika peserta BPJS Mandiri sudah kesulitan membayar iuran, tidak menutup kemungkinan kepesertaannya di BPJS ditanggalkan. Capaian universal health coverage atau cakupan kesehatan semesta pun semakin menjauh dari 100 persen. Dengan demikian, target pemerintah tentang jaminan kesehatan tidak akan tercapai.

\section{Metode Penelitian}

1. Waktu dan Ruang Lingkup Penelitian

Penelitian ini dilakukan selama kurang lebih sepuluh hari sejak akhir bulan Agustus hingga awal bulan September. Adapun penelitian ini mencakup pengelolaan dan pengalokasian dana infak pada enam masjid di Kota Yogyakarta. Tujuan dari penelitian adalah terapan karena penelitian ini dilakukan untuk memperoleh informasi yang dapat digunakan untuk menyelesaikan permasalahan BPJS dilingkungan masyarakat.

2. Sumber Data

Sumber data yang dimaksud dalam penelitian ini adalah darimana subjek data-data penelitian tersebut diperoleh. Dalam penelitian ini didasarkan pada data sekunder yang dikumpulkan berupa laporan keuangan masjid (dana infak). Menurut Sugiyono (2015) data sekunder adalah data yang tidak diperoleh langsung dari lapangan, akan tetapi melalui media tertentu. Sedangkan menurut Tashakkori dan Teddlie (2010) data 
sekunder adalah data yang dicatat atau dikumpulkan pada waktu awal oleh seseorang selain peneliti yang bersangkutan.

3. Teknik Pengumpulan Data

Objek dalam penelitian ini adalah masjid yang berada di kota Yogyakarta. Berdasarkan data Kementrian Agama Wilayah (Kemenag) DIY pada tahun 2014 sebanyak 529 masjid yang ada di Kota Yogyakarta. Akan tetapi, data yang diperoleh dari Kemenag tersebut tidak mengklasifikasikan lebih jelas terkait jumlah warga dan kondisi kesehatan masyarakat di lingkungan masjid. Selain itu, melihat jumlah masjid yang begitu banyak. Oleh karena itu, penelitian ini melakukan survey lapangan dengan mengambil 6 sampel masjid. Adapun sampel dari penelitian dipilih secara purposive dengan mempertimbangkan beberapa aspek, yaitu jumlah warga masyarakat sekitar masjid, jumlah infak/sadaqah yang belum dimanfaatkan, dan laporan keuangan masjid (penerimaan dan pengeluaran).

4. Teknik Analisis Data

Teknik analisis data dalam penelitian ini adalah metode analisis data deskriptif sederhana, yakni dengan memberikan gambaran data tentang jumlah data dan persentase data. Ada 4 jenis data yang disajikan yang dianalisis dalam penelitian, yaitu jumlah warga masyarakat sekitar masjid, jumlah dana infak/sadaqah yang dihimpun dan belum dimanfaatkan oleh masjid di Kota Yogyakarta, dan potensi infak/sadaqah untuk BPJS masyarakat di lingkungan masjid.

\section{Hasil dan Pembahasan}

\section{Keadaan Demografis}

Secara etimologi, kata demografi berasal dari bahasa latin, yaitu "demographie" yang terdiri atas dua kata yakni demos dan graphien demosartinya penduduk, dan graphien yang berarti catatan, bahasan tentang sesuatu hal. Secara etimologi makna demografi adalah pencatatan atau embahasan mengenai penduduk atau daerah disaat waktu tertentu. Berikut merupakan catatan penduduk di lingkungan sekitar masjid dan pengelolaan keungan masjid terkait dana infak/shadaqah.

a. Jumlah Kepala Keluarga dan Jumlah Penduduk Sekitar Masjid

\section{Tabel 2}

\section{Jumlah Penduduk Sekitar dari 6 Masjid}

\begin{tabular}{|c|c|c|c|}
\hline Masjid & KK & Jumlah Jiwa & Presentase (\%) \\
\hline 1 & 334 & 2.259 & $34 \%$ \\
\hline 2 & 226 & 1.530 & $2 \%$ \\
\hline 3 & 176 & 1.414 & $22 \%$ \\
\hline 4 & 176 & 1.412 & $22 \%$ \\
\hline 5 & 103 & 775 & $12 \%$ \\
\hline 6 & 57 & 516 & $8 \%$ \\
\hline Jumlah & 1.072 & 7.906 & $100 \%$ \\
\hline
\end{tabular}

Sumber: 6 sampel masjid Kota Yogyakarta 
Tabel diatas menunjukkan bahwa sebagian besar masyarakat disekitar masjid 1 sebesar $34 \%$, masjid 2 sebesar $2 \%$, masjid 2 sebesar $22 \%$, masjid 4 sebesar $22 \%$, masjid 5 sebesar $12 \%$, dan masjid 6 sebesar $8 \%$.

b. Jumlah Dana Infak yang Dihimpun dan Belum Dimanfaatkan oleh Masjid

Tabel 3

Jumlah dana infak/shadaqah

yang dihimpun yang belum dimanfaatkan dari 6 masjid

\begin{tabular}{|c|c|c|c|}
\hline Masjid & $\begin{array}{l}\text { Jumlah dana } \\
\text { infak/shadaqah } \\
\text { yang dihimpun }\end{array}$ & $\begin{array}{c}\text { Jumlah } \\
\text { pengeluaran }\end{array}$ & $\begin{array}{c}\text { Jumlah dana } \\
\text { infak/shadaqah } \\
\text { yang belum } \\
\text { dimanfaatkan }\end{array}$ \\
\hline 1 & Rp 394,214,950 & $\operatorname{Rp} 267,846,657$ & Rp 126,368,293 \\
\hline 2 & Rp 72,665,850 & Rp 10,795,500 & $\operatorname{Rp} 61,870,350$ \\
\hline 3 & Rp 20,685,165 & Rp 16,739,700 & $\operatorname{Rp} 3,945,465$ \\
\hline 4 & Rp 32,952,600 & Rp 12,635,600 & $\operatorname{Rp} 20,317,000$ \\
\hline 5 & Rp 16,485,000 & Rp 12,414,000 & Rp 20,317,000 \\
\hline 6 & Rp 15,609,000 & Rp 10,080,000 & $\operatorname{Rp} 4,071,000$ \\
\hline Jumlah & Rp 552,612,565 & Rp 330,511,457 & Rp 222,101,108 \\
\hline
\end{tabular}

Tabel diatas menunjukkan bahwa jumlah dana infak yang dihimpun dari 6 masjid dengan pemasukan sebesar Rp 552,612,565 dan pengeluaran sebesar Rp 330,511,457 sedangkan total infak yang belum dimanfaatkan sebesar Rp 222,101,108.

\section{Pengoptimalisasian Dana Infak Masjid yang Belum Dimanfaatkan} untuk Iuran BPJS Kesehatan Masyarakat di Lingkungan Masjid

Berikut merupakan hasil klasifikasi dan persentase jumlah infak yang belum dimanfaatkan untuk membantu iuran BJS kesehatan masyarakat di lingkungan masjid.

\section{Tabel 4}

Jumlah infak/shadaqah untuk BPJS Kesehatan masyarakat di lingkungan Masjid

\begin{tabular}{|c|c|c|c|c|}
\hline Masjid & $\begin{array}{c}\text { Jumlah infak yang } \\
\text { belum } \\
\text { dimanfaatkan }\end{array}$ & $\begin{array}{c}\text { Kelas III } \\
(\mathrm{Rp} \\
306.000 / \text { tahu } \\
\mathrm{n})\end{array}$ & $\begin{array}{c}\text { Kelas II } \\
(\mathrm{Rp} \\
612.000 / \text { tah } \\
\text { un })\end{array}$ & $\begin{array}{c}\text { Kelas I } \\
(\mathrm{Rp} \\
960.000 / \text { tah } \\
\text { un })\end{array}$ \\
\hline 1 & $\operatorname{Rp~126,368,293}$ & 412 jiwa & 206 jiwa & 131 jiwa \\
\hline 2 & $\operatorname{Rp~61,870,350}$ & 202 jiwa & 101 jiwa & 64 jiwa \\
\hline 3 & $\operatorname{Rp~3,945,465}$ & 12 jiwa & 6 jiwa & 4 jiwa \\
\hline 4 & $\operatorname{Rp~20,317,000}$ & 66 jiwa & 33 jiwa & 21 jiwa \\
\hline 5 & $\operatorname{Rp~4,071,000~}$ & 13 jiwa & 6 jiwa & 4 jiwa \\
\hline 6 & $\operatorname{Rp~5,529,000}$ & 18 jiwa & 9 jiwa & 5 jiwa \\
\hline
\end{tabular}




\begin{tabular}{|c|c|r|r|r|}
\hline Total & Rp 222,101,108 & 723 jiwa & 361 jiwa & 229 jiwa \\
\hline $\begin{array}{c}\text { Total masyarakat yang } \\
\text { mendapatkan bantuan iuran } \\
\text { BPJS }\end{array}$ & \multicolumn{3}{|c}{1.313 jiwa } \\
\hline
\end{tabular}

Sumber : Data penelitian yang diolah

Tabel diatas menunjukkan bahwa total masyarakat yang menerima bantuan BPJS kesehatan dari sisa dana infak sebanyak 1.313 jiwa yang terdiri dari kelas III sebanyak 723 jiwa, kelas II sebanyak 361 jiwa, dan kelas I sebanyak 229 jiwa.

\section{Kontribusi Infak Masjid untuk BPJS Kesehatan Masyarakat}

Berdasarkan data yang diperoleh dari instrumen penelitian berupa survey lapangan dan studi literatur, terdapat banyak informasi yang telah dihimpun untuk membantu dalam mengatasi iuran BPJS Kesehatan bagi masyarakat yang berada di lingkungan masjid. Merujuk pada data sebelumnya yang menunjukkan bahwa jumlah penduduk di sekitar masjid terbanyak di 3 masjid yaitu masjid 1, masjid 3, dan masjid 4. Sedangkan pada masjid 2 jumlah penduduk di sekitar masjid tersebut hanya $2 \%$, masjid 5 sebesar $8 \%$, dan masjid 6 sebesar 12\%. Dana infak yang dikumpulkan oleh manajemen masjid tercatat pemasukan sebesar Rp 552,612,565 dan pengeluaran sebesar Rp 330,511,457, sedangkan total dana infak yang belum dimanfatkan oleh masjid tersebut sebesar Rp 222,101,108. Jumlah dana yang belum dimanfaatkan atau dana menganggur dari 6 masjid merupakan jumlah yang signifikan. Hal tersebut dapat diproyeksikan terhadap akumulasi jumlah pemasukan masjid yang ada di Kota Yogyakarta yaitu 529 masjid.

Selain itu, data menunjukkan bahwa jumlah dana infak masjid untuk BPJS Kesehatan masyarakat di lingkungan masjid berjumlah Rp 222.101.108. Kemudian, dilakukan perhitungan untuk penerima BPJS kesehatan masyarakat dengan kelas yang berbeda maka hasilnya adalah kelas III sebanyak 723 jiwa, penerima di kelas II sebanyak 361 jiwa dan 229 jiwa untuk penerima kelas I. Sehingga total penerima BPJS kesehatan di lingkungan masjid berjumlah 1.313jiwa. Maka dapat dilihat bahwa pengoptimalisasian dana infak yang menganggur dapat berkontribusi nyata bagi masyarakat yang terdaftar sebagai peserta BPJS kesehatan dan kesulitan untuk membayar iuran.

Kontribusi dana infak masjid untuk memberikan bantuan dana kepada masyarakat merupakan ide yang perlu dikembangkan melihat kontribusi tersebut sangat berpotensi dan aplikatif. Selain itu, keberadaan masjid dalam menjalankan fungsi dan perannya terkait pemberdayaan umat akan terlihat jelas. Hal tersebut dikarenakan jaminan kesehatan masyarakat adalah kebutuhan dasar yang diperlukan oleh masyarakat.

\section{Kesimpulan}

Dari hasil penelitian ini dapat disimpulkan bahwa dana infak yang dihimpun oleh manajemen masjid yaitu sebesar Rp 552.612.565, dana yang telah dialokasikan sebesar Rp 330.511.457. Sedangkan dana yang belum dimanfaatkan sebesar Rp 222.101.108. 
Kemudian diperoleh jumlah masyarakat yang dapat menerima bantuan BPJS kesehatan sebanyak 1.313 jiwa yang terdiri dari kelas III sebanyak 723 jiwa, kelas II sebanyak 361 jiwa, dan kelas I sebanyak 229 jiwa.

Oleh karena itu hasil dari studi ini ditemukan bahwa pengoptimalisasian infak mampu membantu dalam menyelesaikan masalah perekonomian masyarakat lingkungan sekitar masjid, khususnya dalam mengatasi iuran BPJS Kesehatan. Selain itu pengoptimalisasian dana infak ini juga menjadi konsep baru dan integratif yang dapat diaplikasikan di masjid Kota Yogyakarta dan Indonesia secara umum sebagai salah satu solusi dalam mengatasi persoalan umat.

\section{Saran}

Melalui penyusunan Karya Tulis Ilmiah ini, penulis berusaha memberikan beberapa saran yaitu mengoptimalkan sisa dana infak masjid agar dapat bermanfaat bagi masyarakat sekitar masjid. Di samping itu, pemerintah mewajibkan seluruh masjid mengoptimalkan sisa dana infak untuk membantu masyarakat berpendapatan rendah dalam membayar iuran BPJS Kesehatan dan menjadikan penelitian ini sebagai acuan untuk penelitian selanjutnya

\section{DAFTAR PUSTAKA}

(n.d.). Retrieved from https://m.merdeka.com/uang/dampak-kenaikan-iuran-bpjskesehatan-antara-defisit-dan-kemiskinan.html (n.d.). Retrieved 09 09, 2019, from https://yogyakarta.kemenag.go.id (2011). Retrieved from BPJS kesehatan: http://bpjs-kesehatan.go.id Abdul Muta Ali. (2018). (PDF) Prektek Badan Penyelenggara Jaminan Sosial (Analisis Hukum Ekonomi Syariah). Retrieved from https://www.researchgate.net/publication/327743891_Prektek_Badan_Penyelengg ara_Jaminan_Sosial_Analisis_Hukum_Ekonomi_Syariah

Nasutioan Abdul Haris, Khoirun, N., Askari, Z., \& Muhammad, Z. (n.d.). (PDF) Kajian

Strategi Zakat, Infaq Dan Shadaqah Dalam Pemberdayaan Umat. Jurnal Ekonomi Bisnis Syariah, (Kajian Strategi dan Pemberdayaan Ummat). Retrieved from https://www.researchgate.net/publication/327861107_Kajian_Strategi_Zakat_Infa q_Dan_Shadaqah_Dalam_Pemberdayaan_Umat

Nurlaelawati, E. (2010). Zakat and the Concept of Ownership in Islam: Yusuf Qaradawi's Perspective on Islamic Economics. Al-Jami'ah: Journal of Islamic Studies, 48(2), 365. https://doi.org/10.14421/ajis.2010.482.365-385

Priyatna, A. R. (2018). Aspek-Aspek Filosofis Zakat Menurut Alqur'an dan Sunah. Adrkiya: Jurnal Hukum Dan Ekonomi Syariah. https://doi.org/10.32332/adzkiya.v6i2.1332 
Rifai, A. B., \& Fakhruroji, M. (2005). Manajemen masjid: mengoptimalkan fungsi sosial-ekonomi masjid. Benang Merah Press.

Sidi Gazalba. (1983). Lokasi: Masjid Pusat Ibadah dan Kebudayaan Islam (Banten, ed.). Retrieved from http:/ / opac.ushuluddin.uinjkt.ac.id//index.php?p=show_detail\&id=1785

Sochimin, S. (2016). Praktik Manajemen Keuangan Masjid Berbasis Pemberdayaan Ekonomi Umat Di Kota Purwokerto. Jurnal Penelitian Agama, 17(2), 290-312. https://doi.org/10.24090/jpa.v17i2.2016.pp290-312

Usman, C., \& Kara, M. (2016). Analisis Pengelolaan BPJS Kesehatan Dalam Perspektif Ekonomi Islam (Studi Kasus BPJS Kesehatan Makasar). Jumal Iqtisaduna, 2(1), 6985. https://doi.org/10.24252/iqtisaduna.v2i1.2397 